\title{
Social-Ecological Evolutionary Resilience: A Proposal to Enhance "Sustainability Transformation" about Theoretical Foundation
}

\author{
Qiyan Wang, Masakazu Yamashita \\ Department of Environmental Systems Science, Doshisha University, Kyoto, Japan \\ Email: eun1902@mail4.doshisha.ac.jp
}

Received 28 February 2015; accepted 15 March 2015; published 20 March 2015

Copyright (C) 2015 by authors and OALib.

This work is licensed under the Creative Commons Attribution International License (CC BY). http://creativecommons.org/licenses/by/4.0/

(c) (i) Open Access

\begin{abstract}
In this conceptual paper, we try to take a step to explore theoretical foundation of sustainability transformation in dimension of resilience thinking. Firstly, this paper will reexamine the ontology of ecosystem resilience so as to avoid the conflated view between ecosystem resilience and engineering resilience; secondly, it will propose social-ecological evolutionary resilience as theoretical and conceptual foundation for sustainability transformation.
\end{abstract}

\section{Keywords}

Resilience Thinking, Social-Ecological Evolutionary, Ecosystem Resilience, Engineering Resilience

\author{
Subject Areas: Environmental Sciences
}

\section{Introduction}

There is no doubt that we are living in a world with challenging times and "persistent problems” [1]-[3]. It constantly reminds us of "business as usual” and "status quo" failures and the need to realize "true sustainability" by radical systematic change.

Consequently, transformations as powerful and hopeful research concept and world of view have been getting considerable attention, and resilience thinking and transition approach are as two inspiriting theoretical and conceptual frameworks for studying sustainability transformation. Notwithstanding, an unambiguous understanding of the underlying mechanisms and patters, as well as conditions, of transformation, which would strikingly increase our opportunities for escaping from “vicious unsustainable stuckness” and successfully navigating prominent transformation to sustainability, is still in infancy [4]. But more than that, the critical question is 
that what theoretical and conceptual foundation of sustainability transformation is; if resilience thinking is a power conceptual framework, what exactly resilience thinking is and how resilience thinking can provide basis for sustainability transformation.

In this paper, we try to take a step to explore theoretical foundation of sustainability transformation in dimension of resilience thinking. Firstly, this paper will reexamine the ontology of ecosystem resilience so as to avoid the conflated view between ecosystem resilience and engineering resilience; secondly, it will propose socialecological evolutionary resilience as theoretical and conceptual foundation for sustainability transformation.

\section{Ecosystem Resilience}

Not surprisingly, it appears that the coming wave of "resilience" has prevailed around the entire world. Many research programs, governmental and non-governmental reports are labeled as "resilience-building", which might have this hopeful concept and theory reduced to a useless slogan, or even be distorted far away from its essential meaning. In this section, we will attempt to go into the essence of ecosystem resilience so as to peel off the misunderstanding conflation between ecosystem resilience and engineering resilience.

\subsection{Ecosystem Resilience VS Engineering Resilience}

As indicated by Hull [5], conceptual advancement is motivational engine for scientific progress. Following this perspective, it is a good reason to explore and clarify ecosystem resilience concept given that it is as theoretical and conceptual "building blocks" of sustainability transformation.

Holling [6] first introduces ecosystem resilience as a concept emphasizing the existence of multiple stability domains in ecological system and the capacity and persistence of ecosystem when facing disturbances. Accordingly, ecosystem resilience is defined as measure of the persistence of systems and of their ability to absorb change and disturbance and still maintain the same relationships between populations or state variables [6] or magnitude of disturbance that can be absorbed before the system changes its structure by changing the variables and processes that control behavior [7]. Correspondingly, engineering resilience refers to the time a system takes to recover from a disturbance [8] or as rate and speed of return to pre-existing and original conditions after disturbance [7]. The difference is that ecosystem resilience rejects mechanical equilibrium, and concentrates on the possibilities of systems to flip into an irreversible alternative basin of attraction, while engineering resilience emphasizes "global stability" and the existence of a one single and stable equilibrium [6]. Simple put, engineering resilience is obsessed with "efficiency, constancy and predictability [9]".

Unfortunately, there is a tendency when continuing to develop and broaden ecosystem resilience concept that ecosystem resilience is mistakenly interpreted as "returning and recovering original and pre-existing normal state" or "maintaining and preserving what we have" [10]. As Tanner, et al. [11] argue, "to avoid thinking about things more radically; it is a convenient word like resilience or sustainability and has moved from an initial more radical meaning to one that is likely to be co-opted into existing system which want to avoid transformation.” In other words, ecosystem resilience in many cases and discourses explicitly and implicitly boils down to engineering resilience as "bounce back" [12]. If ecosystem resilience itself has confusion about what it is and what it will be, its successors might easily head in the wrong direction. It is that issue that the 2.2 Section now turns to.

\subsection{A Back to Essence}

Given that ecosystem resilience has been channeled into wider research fields with multi-conceptual structure dimensions. It begs an inevitable question that: Since ever-increasing definitional meanings and practices in various scientific disciplines, on the one hand, result in diversity which to some extent can improve richness of resilience approach and promote communication between and among different scientific researches, on the other hand, ambiguousness which can undermine and dilute the original power in resilience approach [13], based on what essence in resilience concept can conceptual structure diversification be encouraged while conceptual clarity power be conserved? The word of essence is defined as: "the basic nature of a thing - the quality or qualities that make a thing what it is" [14]; "the intrinsic nature or indispensable of something, especially something abstract, which determines its character" [15]. In other words, essence as the basic abstract nature of resilience concept meaning that determines its scopes, directions and applications in conceptual development can be explicitly or implicitly presented in diverse conceptual variants and derivate-in part or in whole. 
Obviously, the underlying connection to original meaning is still implicitly and well conserved and then inherited by successors, although the term, resilience, has been endowed different definitions (Table 1), employed by multiple disciplines so as far to be changed considerably compared to the original definition. The original ecological meaning of resilience is defined as "measure of the persistence of systems and of their ability to absorb change and disturbance and still maintain the same relationships between populations or state variables" [6]. We argue that this definition is composed of six interconnected and replaceable "building blocks": persistence, populations, ecosystems, disturbance, ability and collapse. Not only do these building blocks include state, dynamics, process, forces and systems, but also combine together to define research object, subject and direction.

It can be found that the conceptual development following original-ecosystem resilience concept is built by in-depth re-exploring the above six building blocks such as substituting one or more elements and then recombining them. One typical case is that resilience concept is introduced into social system [16], ecological-economic system [17] [18], or social-ecological system [19]-[21], respectively, in which cases system is reset. Other typical examples are manifested as substituting research object while still in ecological system or deepening ecosystem dynamics [7] [22]-[28]. Thus, our proposition is that the essence of ecosystem resilience the capacity and process of positive changes and changing the changes positively between persistence and collapse or between 0 and 1 [28] with or without external disturbances. As such, the key words are capacity, process, persistence and change. In Oxford Dictionaries [15], persistence is defined as: 1) continuing firmly or obstinately in an opinion or course of action in spite of difficulty or opposition; 2) continuing to exist or occur over a prolonged period; 3) remaining within the environment for a long time after introduction; 4) remaining attached instead of falling off in the normal manner. By definition, it indicates that "to continue when facing difficulties while still within critical threshold in long-time dimension" is the core meaning of persistence, which also signifies existence and even sustainability of social-ecological systems. Persistence and collapse exhibit the extreme endpoints on the spectrum of the conceptual meaning of resilience. Change as effect and cause of persistence can positive, or negative, and irreversibly incremental or radical. The connotations of ecosystem concept are that: resilience as system property can be studied in different systems, e.g., ecological system, social system, social-ecological system, and different systems can have different combinations of capacity, process, persistence and change, the option of which combinations depending on specific research plan and different philosophy perspective are not contradictory (be it Antropocentric or Ecocentric). It is obvious that the essence of ecosystem resilience is open, inclusive and fundamental dynamic. In the next section, we will turn to the meaning of ecosystem resilience based-resilience thinking.

Table 1. Some definitions of resilience concept.

\begin{tabular}{|c|c|}
\hline References & Definitions of Resilience \\
\hline$[6]$ & $\begin{array}{l}\text { Measure of the persistence of } 65 \text { systems and of their ability to absorb change and disturbance and still maintain the same } \\
\text { relationships between populations or state variables }\end{array}$ \\
\hline [7] & $\begin{array}{l}\text { The magnitude of disturbance that can be absorbed before the system changes its structure by changing the variables and } \\
\text { processes that control behavior }\end{array}$ \\
\hline$[21]$ & $\begin{array}{l}\text { The capacity of a system to experience shocks while retaining essentially the same function, structure, } \\
\text { feedbacks, and therefore identity }\end{array}$ \\
\hline [22] & Capacities 1) to absorb disturbances, 2) for self-organization, and 3) for learning and adaptation \\
\hline [24] & Quantitative property that changes throughout ecosystem dynamics and occurs on each level of an ecosystem's hierarchy \\
\hline [26] & The ability of the system to maintain its identity in the face of internal change and external shocks and disturbances \\
\hline [16] & $\begin{array}{l}\text { The ability of groups or communities to cope with external stresses and disturbances as a result of social, political, } \\
\text { and environmental change }\end{array}$ \\
\hline$[17]$ & Transition probability between states as a function of the consumption and production activities of decision makers \\
\hline$[28]$ & $\begin{array}{l}\text { The ability of the system to withstand either market or environmental shocks without loosing the capacity to allocate } \\
\text { resources efficiently }\end{array}$ \\
\hline$[20]$ & $\begin{array}{l}\text { The underlying capacity of an ecosystem to maintain desired ecosystem services in the face of a fluctuating } \\
\text { environment and human use }\end{array}$ \\
\hline [19] & $\begin{array}{l}\text { The capacity of a social-ecological systems to absorb recurrent disturbances (...) so as to retain essential structures, } \\
\text { processes and feedbacks }\end{array}$ \\
\hline [21] & A perspective or approach to analyze social-ecological systems \\
\hline
\end{tabular}

Data Adapted from Fridolin Simon Brandt and Kurt Jax, 2007. 


\section{Ecosystem Concept-Based Resilience Thinking}

Before introducing resilience thinking, we will make conceptual difference between resilience theory, ecosystem resilience, engineering resilience and resilience thinking. We argue that resilience theory conceptually ranges from descriptive resilience [13], as one endpoint, to resilience thinking, as the other endpoint [29]. Among them, descriptive resilience includes two conceptual layers, ecosystem resilience and engineering resilience, respectively, which means that resilience thinking is easy to inadvertently sneak into "engineering resilience” zone. In this section, we will attempt to pull resilience thinking out of engineering resilience.

\subsection{Resilience Thinking}

Resilience thinking rooted in ecosystem resilience is developed resting on a range of research papers and books, among which Resilience Thinking: Integrating Resilience, Adaptability and Transformability, is the most quintessential of papers. The promising endowments of this paper are that: 1) ecosystem resilience is extended from ecological system into social-ecological system; 2) another new two concepts, adaptation and transformation are added as essential perquisites for social-ecological resilience; 3) confusion between resilience and transformation is tactfully resolved by "multi-scalar and temporal resilience” perspective; 4) three aspects of social-ecological system is addressed: resilience as persistence, adaptability, transformability [10]. So, to put is another way, resilience thinking provides a conceptual and theoretical entrance by which we can genuinely integrate the ecological sphere and the social sphere, that is, social-ecological system and can map feedbacks and interactions between resilience, adaptation and transformation in multi-spatial and temporal level onto social-ecological system. However, it is a pity that resilience and adaptation is, implicitly or explicitly, similarly understood as "maintenance", "recovering to the original state" or "business as usual” when applied in wider research fields, like climate change research, community research and disaster research, to name a few. As O’Brien [30] points out, in the process of dealing with global environmental change most studies have paid much close attention to accommodating changes, though, which also focuses on transformative changes, while less attention to creating changes proactively. Just like ecosystem resilience is trapped into engineering resilience zone, resilience thinking, which erroneously is guided by engineering resilience, is fettered by adaptation determinism.

\subsection{Social-Ecological Evolutionary Resilience}

Tracing research development founded on resilience thinking, we identify two basic conceptual dimensions of resilience thinking, we call, social-ecological non-evolutionary resilience and social-ecological evolutionary resilience (Table 2), which recognition is helpful to tell between resilience and adaptation, and between ecosystem concept and engineering concept.

As shown in Table 2, social-ecological non-evolutionary resilience is characterized as: buffer capacity for preserving what we have and recovering to where we have; all about absorbing shocks; survival and bounceback ability and process; avoiding negative regime shift and keeping staying the "original” regime; adaptive resilience, while social-ecological evolutionary resilience thinking is featured as the ability to change, adapt, and

Table 2. Some characteristics of social-ecological non-evolutionary resilience and social-ecological evolutionary resilience.

Social-Ecological Non-Evolutionary Resilience Thinking

- As buffer capacity for preserving what we have and recovering to where we have [10]

- All about absorbing shocks

- Survival and Bounce-Back ability and process [39] [40]

- $\quad$ Resilience 1.0 [41]

- Avoiding negative regime shift and keeping staying the “original” regime (Disturbances and shocks move SES into alternative undesirable regime within the same system or into another undesirable regime within different system.)

- Conservative connotation

- Adaptive resilience [36] [42]-[45]
Social-Ecological Evolutionary Resilience Thinking

- As the ability to change, adapt, and importantly transform with or without external disturbance and as the process to continually reinvent and innovate for doing new things and new possibilities with hope [10] [33] [46]

- Not necessarily about absorbing shocks

- Bounce forward, to-forth and bounce beyond ability and process [39] [47]

- $\quad$ Resilience 2.0 [41]

- To change and not to continue doing the same thing and to be stronger and better than before [48]

- Positive and active regime shift with intentionality of human actions

- Radical connotation

- Transformative resilience [32] [41]

- Evolutionary resilience [33] 
importantly transform with or without external disturbance and as the process to continually reinvent and innovate for doing new things and new possibilities with hope; not necessarily about absorbing shocks; bounce forward, to-forth and bounce beyond ability and process; to change and not to continue doing the same thing and to be stronger and better than before; positive and active regime shift with intentionality of human actions; transformative resilience. Among them, the two concepts, adaptive resilience and transformative resilience are widely used, which zooms in the separation between adaptive capacity and transformative capacity, between adaptive process and transformative process. Adaptive resilience refers to "the various adjustments (incremental changes) that people undergo in order to continue functioning without major qualitative changes in function or structural identity [31]," while transformative resilience [32] directs its attention to the capacity and ability to revitalize communities, cities, or regions with radical new relationships, modes of organization, and networks, not just returning to normal or the status quo or a pre-trauma.

It is apparent that the social-ecological evolutionary residence takes root in ecosystem resilience; social-ecological non-evolutionary resilience in engineering resilience. The term, social-ecological evolutionary resilience is inspired by [12] [33]. Simmie and Martin [33] reconsider resilience as ongoing changing process rather than just the capacity to recovery by linking evolutionary perspective with resilience thinking in study of regional economic resilience in order to avoid the "equilibrist trap" in the concept of resilience thinking, or to put it another way, the conflations between ecosystem resilience and engineering resilience. Davoudi [12] [34] follows this discussion and proposes, she calls, evolutionary resilience, instead of social-ecological resilience: an unceasingly changing process and a "becoming", not as a settled property and a "being". Thus, evolutionary resilience draws attention to the process and ability of complex social-ecological system to change, adapt, and more importantly, transform, instead of "back-to-normality", which coincides with the essence of ecosystem resilience we suggest. It is social-ecological evolutionary resilience to we should turn as theoretical and conceptual foundation for sustainability transformation. The reason why we use the term, social-ecological evolutionary resilience, is that we accentuate change process and ability playing in the stage of complex adaptive social-ecological system, not ecological system or social system. It means that social-ecological system as a unique system differs from ecological system and social system, which is consistent with resilience perspective and sustainability science. Social-ecological evolutionary resilience as a weathervane can direct the development of interdisciplinary research when translating resilience thinking into, or integrating resilience thinking with other research fields. As Mcevory and Fünfgeld [35] argue, there are two prominent inconsistences and alienations: to mostly concern with "staying the status quo", while to ignore transformation potential and process; to bound itself within "engineering resilience" which underlines "bouncing back to the previous stable state as soon as possible”. Nilakant, V., et al. [36] argue that there are two dimensions constituting resilience concept, one of which is called first-order resilience involving pre-disasters activities, while the other of which is second-order resilience or adaptive resilience referring post-disasters responding, learning and renewing activities. Obviously, these two dimensional resilience concepts mostly situate themselves within social-ecological non-evolutionary resilience or adaptive resilience. Sustainability transformation is usually defined as "shifts that fundamental alter human and environmental interactions and feedbacks [4]" or as "physical and/or qualitative changes in form, structure, or meaning-making [37]" or as "the capacity to create untried beginnings from which to evolve a fundamentally new way of living when existing ecological, economic, and social conditions make the current system untenable [38]". Apparently, these above definitions of sustainability transformation match with social-ecological evolutionary resilience perfectly. But it is worth noting that social-ecological non-evolutionary resilience and socialecological evolutionary is not completely opposite to each other, which depends on concrete research subject and object. To great degree, social-ecological non-evolutionary resilience only expresses naïve appeal and comfort. In other words, we can choose to return and recover, but not to the original one, to a "new original one", to this point, which is connected with social-ecological evolutionary resilience.

\section{Conclusion}

The research on social-ecological transformation to sustainability is just at the bringing and sustainability transformation is mostly staying at a rhetorical phase as slogan or hairpiece. It is imperative to synthesize and integrate achievements already made in the existing research fields such as resilience thinking and transition approach or other inspiring research fields, such as complex adaptive system theory or some social theory like structure and agency theory. 
In future research, we will continue to explore three issues: the first one is how to use this theoretical framework to increase the understanding of the mechanisms and patterns, as well as conditions, underlying socialecological transformations; the second one is that many studies deem social-ecological system as a backdrop. We assume that social-ecological system is as a unique complex adaptive system that is different from social system or ecological system. For sustainability transformation processes exist in social-ecological system, it is critical to conceptualize social-ecological system for better mapping transformative process; the third one is that the interaction between structure and agency is one of the critical conceptual layers within social-ecological system which is still ignored in resent studies. So how do we bring a theory of structure and agency into studies on transformation to social-ecological sustainability?

\section{Acknowledgements}

Writers would like to express their thanks to Department of Environmental Systems Science, Doshisha University, for partial financial support of this research.

\section{References}

[1] Rotmans, J. (2005) Societal Innovation: Between Dream and Reality Lies Complexity. Inaugural Address, Erasmus Research Institute of Management, Erasmus University Rotterdam.

[2] Loorbach, D. (2007) Transition Management, New Mode of Governance for Sustainable Development. Ph.D. Dissertation, Erasmus University Rotterdam, International Books.

[3] Loorbach, D., van Bakel, J.C., Whiteman, G. and Rotmans, J. (2009) Business Strategies for Transitions towards Sustainable Systems. Business Strategy and the Environment, Published online in Wiley InterScience, 10.1002.

[4] Olsson, P., Galaz, V. and Boonstra, W.J. (2014) Sustainability Transformations: A Resilience Perspective. Ecology and Society, 19, 1. http://dx.doi.org/10.5751/ES-06799-190401

[5] Hull, D.L. (1988) Science as a Process. University of Chicago Press, Chicago. http://dx.doi.org/10.7208/chicago/9780226360492.001.0001

[6] Holling, C.S. (1973) Resilience and Stability of Ecological Systems. Annual Review of Ecological and Systematics, 4, 1-23. http://dx.doi.org/10.1146/annurev.es.04.110173.000245

[7] Gunderson, L.H. and Holling, C.S. (2002) Panarchy: Understanding Transformations in Human and Natural Systems. Island Press, Washington.

[8] Pimm, S.L. (1984) The Complexity and Stability of Ecosystems. Nature, 307, 321-326. http://dx.doi.org/10.1038/307321a0

[9] Holling, C.S. (1996) Engineering Resilience versus Ecological Resilience. In: Schulze, P.E., Ed., Engineering within Ecological Constraints, National Academy Press, Washington DC, 31-43.

[10] Folke, C., Carpenter, S.R., Walker, B., Scheffer, M., Chapin, T. and Rockström, J. (2010) Resilience Thinking: Integrating Resilience, Adaptability and Transformability. Ecology and Society, 15, 20. http://www.ecologyandsociety.org/vol15/iss4/art20/

[11] Tanner, T.M. and Bahadur, A.V. (2013) Distilling the Characteristics of Transformational Change in a Changing Climate. Proceedings of Transformation in Changing Climate International Conference, Oslo, 19-21 June 2013, 33-42.

[12] Davoudi, S. and Porter, L. (2012) Resilience: A Bridging Concept or a Dead End? Planning Theory \& Practice, 13, 299-307. http://dx.doi.org/10.1080/14649357.2012.677124

[13] Brand, F.S. and Jax, K. (2007) Focusing the Meaning(s) of Resilience: Resilience as a Descriptive Concept and a Boundary Object. Ecology and Society, 12, 23. http://www.ecologyandsociety.org/vol12/iss1/art23/

[14] Merriam-Webster (2015) http://www.merriam-webster.com/.

[15] Oxford Dictionaries (2015) http://www.oxforddictionaries.com/.

[16] Adger, W.N. (2000) Social and Ecological Resilience: Are They Related? Progress in Human Geography, 24, 347-364. http://dx.doi.org/10.1191/030913200701540465

[17] Brock, W.A., et al. (2002) Resilience and Sustainability: The Economic Analysis of Nonlinear Dynamic Systems. In: Gunderson, L.H. and Holling, C.S., Eds., Panarchy: Understanding Transformations in Human and Natural Systems, Island Press, Washington DC, 261-289.

[18] Perrings, C.A. (2006) Resilience and Sustainable Development. Environment and Development Economics, 11, 417427. http://dx.doi.org/10.1017/S1355770X06003020 
[19] Adger, W.N., Hughes, T.P., Folke, C., Carpenter, S.R. and Rockström, J. (2005) Social-Ecological Resilience to Coastal Disasters. Science, 309, 1036-1039. http://dx.doi.org/10.1126/science.1112122

[20] Folke, C., Carpenter, S., Elmqvist, T., Gunderson, L., Holling, C.S. and Walker, B. (2002) Resilience and Sustainable Development: Building Adaptive Capacity in a World of Transformations. AMBIO, 31, 437-440.

[21] Folke, C. (2006) Resilience: The Emergency of a Perspective for Social-Ecological Systems Analyses. Global Environmental Change, 16, 253-267. http://dx.doi.org/10.1016/j.gloenvcha.2006.04.002

[22] Walker, B., Gunderson, L., Kinzig, A., Folke, C., Carpenter, S. and Schultz, L. (2006) A Handful of Heuristics and Some Propositions for Understanding Resilience in Social-Ecological Systems. Ecology and Society, 11, 13. http://www.ecologyandsociety.org/vol11/iss1/art13/

[23] Walker, B., Carpenter, S., Anderies, J., Abel, N., Cumming, G.S., Janssen, M., et al. (2002) Resilience Management in Social-Ecological Systems: A Working Hypothesis for a Participatory Approach. Ecology and Society, 6, 14. http://www.consecol.org/vol6/iss1/art14/

[24] Folke, C., Carpenter, S., Walker, B., Scheffer, M., Elmqvist, T., Gunderson, L., et al. (2004) Regime Shifts, Resilience, and Biodiversity in Ecosystem Management. Annual Review of Ecology, Evolution and Systemtics, 35, 557-581. http://dx.doi.org/10.1146/annurev.ecolsys.35.021103.105711

[25] Holling, C.S. (2001) Understanding the Complexity of Economic, Ecological and Social Systems. Ecosystems, 4, 390405. http://dx.doi.org/10.1007/s10021-001-0101-5

[26] Carpenter, S.R., Walker, B., Anderies, J.M. and Abel, N. (2001) From Metaphor to Measurement: Resilience of What to What. Ecosystems, 4, 765-781. http://dx.doi.org/10.1007/s10021-001-0045-9

[27] Cumming, G.S. and Collier, J. (2005) Change and Identity in Complex Systems. Ecology and Society, 10, 29. http://www.ecologyandsociety.org/vol10/iss1/art29/

[28] Perrings, C.A. (2006) Resilience and Sustainable Development. Environment and Development Economics, 11, 417427. http://dx.doi.org/10.1017/S1355770X06003020

[29] Strunz, S. (2012) Is Conceptual Vagueness an Asset? Arguments from Philosophy of Science Applied to the Concept of Resilience. Ecological Economics, 76, 112-118. http://dx.doi.org/10.1016/j.ecolecon.2012.02.012

[30] O’Brien, K. (2011) Global Environmental Change II : From Adaptation to Deliberate Transformation. Progress in Human Geography, Published Online.

[31] Béné, C., et al. (2012) Resilience: New Utopia or New Tyranny? Reflection about the Potentials and Limits of the Concept of Resilience in Relation to Vulnerability Reduction Programmes. IDS Working Papers, 2012, 1-61. http://dx.doi.org/10.1111/j.2040-0209.2012.00405.x

[32] Gotham, K. and Campanella, R. (2010) Toward a Research Agenda on Transformative Resilience: Challenges and Opportunities for Post-Trauma Urban Ecosystems. Critical Planning Summer.

[33] Simmie, J. and Martin, R. (2010) The Economic Resilience of Regions: Towards an Evolutionary Approach. Cambridge Journal of the Regions, Economy and Society, 3, 27-43.

[34] Davoudi, S. (2011) The Legacy of Positivism and the Emergence of Interpretive Tradition in Spatial Planning. Regional Studies, 46, 1-13.

[35] Mcevory, D. and Fünfgeld, H. (2011) Resilience as a Useful Concept for Climate Change Adaptation? Planning Theory \& Practice, 13, 324-328.

[36] Nilakant, V., Walker, B., van Heugen, K., Baird, R. and de Vries, H. (2014) Research Note: Conceptualising Adaptive Resilience Using Grounded Theory. New Zealand Journal of Employment Relations, 39, 79-86.

[37] O’Brien, K. and Sygna, L. (2013) Responding to Climate Change: The Three Spheres of Transformation. Proceedings of Transformation in Changing Climate International Conference, Oslo, 19-21 June 2013, 16-23.

[38] Westley, F., Olsson, P., Folke, C., Homer-Dixon, T., Vredenburg, H., Loorbach, D., Thompson, J., Nilsson, M., Lambin, E., Sendzimir, J., Banerjee, B., Galaz, V. and van der Leeuw, S. (2011) Tipping toward Sustainability: Emerging Pathways of Transformation. AMBIO, 40, 762-780. http://dx.doi.org/10.1007/s13280-011-0186-9

[39] Shaw, K. (2012) "Reframing” Resilience: Challenges for Planning Theory and Practice. Planning Theory \& Practice, 13, 308-312.

[40] Valikangas, L. (2010) The Resilient Organization: How Adaptive Cultures Thrive Even When Strategy Fails. McGrawHill, New York.

[41] Hodgson, A. (2011) Is Resilience Enough? Decision Integrity Limited International Futures Forum.

[42] Wilson, S., Pearson, L.J., Kashima, Y., Lusher, D. and Pearson, C. (2013) Separating Adaptive Maintenance (Resilience) and Transformative Capacity of Social-Ecological Systems. Ecology and Society, 18, 22. http://dx.doi.org/10.5751/ES-05100-180122 
[43] Robinson, M. (2010) Making Adaptive Resilience Real. Arts Council England, London.

[44] Anthony, K., et al. (2015) Operationalizing Resilience for Adaptive Coral Reef Management under Global Environmental Change. Global Change Biology, 21, 48-61. http://dx.doi.org/10.1111/gcb.12700

[45] Cutter, S., Barnes, L., Berry, M., Burton, C., Evans, E., Tate, E. and Webb, J. (2008) A Place-Based Model for Understanding Community Resilience to Natural Disasters. Global Environmental Change, 18, 598-606. http://dx.doi.org/10.1016/j.gloenvcha.2008.07.013

[46] Scheffer, M. (2009) Critical Transitions in Nature and Society. Princeton University Press, Princeton.

[47] Leach, M. (2008) Re-Framing Resilience: A Symposium Report. STEPS Centre, Brighton.

[48] Seville, E. (2009) Resilience: Great Concept but What Does It Mean for Organizations? In: Ministry of Civil Defense and Emergency Management, Eds., Community Resilience: Research, Planning and Civil Defense Emergency Management, Ministry of Civil Defense \& Emergency Management, Wellington, 9-14. 